\title{
The Development Of Tracer Study System For PEP Alumni Graduate School Unnes By Online Based On The Website
}

\author{
S. Supriyadi ${ }^{1}$, W. Isnaeni ${ }^{2}$, A. Rusilowati ${ }^{3}$ \\ \{ supriyadi@mail.unnes.ac.id ${ }^{1}$,wiwiisna@mail.unnes.ac.id ${ }^{2}$, rusilowati@mail.unnes.ac.id ${ }^{3}$ \}
}

Graduate School, Universitas Negeri Semarang, Indonesia ${ }^{1,2,3}$

\begin{abstract}
The background of the study is needs of PEP study programs about alumni data and users for the necessity of the development of study programs and accreditation. The study aims to develop an effective way of tracer study, which is easy to use, easy to access information, and able to provide detailed feedback. The method of collecting data with distributed instruments in the form of open and closed questionnaires through the website that has been made. Research on tracer study alumni was conducted with online media including WhatsApp messenger, email, website and google form applications. The results of the study showed that the most complete information is collected by Google form and website. But google form has limitations because just be accessed by the admin using the email registered on the google form. The easiest system to access information, and able to provide detailed feedback, is the system who was developed online based on the website.
\end{abstract}

Keywords: Tracer study, google form, website

\section{Introduction}

Educational Research and Evaluation or Penelitian dan Evaluasi Pendidikan (PEP) S2 Study Program is one of the study programs at the Graduate School Program at Universitas Negeri Semarang (UNNES). In the guidebook of the PEP UNNES [1] it was stated that there were a number of objectives that would be got by the PEP study program. Two objectives include improving the quality of education by increasing resources in the field of research and evaluation and producing graduates who have superior qualifications in the field of education research and evaluation. This means that PEP study program needs to do at least two things, namely 1) evaluating the learning process held by study programs, and 2) monitoring or tracking the quality of alumni in the field. The activity was basically intended to evaluate the level of achievement of objectives, which can be done through tracking or tracer studies. Tracer study is one form of an empirical study to evaluate educational outcomes. Tracer studies can be used as a tool to overcome problems related to curriculum relevance, knowledge, expertise and work values. It is also important to overcome problems related to quality and support services for training activities, as well as to identify one's personal and professional character intended to improve the competence and feasibility of graduates in the job market [2]Tracer study was intended to evaluate graduates' responses from the alma mater's performance [3][14][15]. This is consistent with Zainul's (2001) statement that evaluation needs to be applied to all components involved in the learning process, including input, process, and output. In this research, a tracer study is emphasized to evaluate the process, output or output, and the outcome. The output was 
PEP study program alumni who had just graduated from the PEP study program, within 0-years, while the outcome was alumni who had graduated a year or more.

According to Setyorini, et al. (2012) the results of the tracer study can be used in the National Higher Education Accreditation Body (BAN-PT) [8]. In this study, the information was explored about two main things, namely the quality of the learning process held by the PEP study program, and the quality of the alumni in the field, after they graduated from being declared graduated from the PEP study program. A core requirement will be to leverage existing national data and analytics strategies and frameworks. The strategy is by identifying the analytics and data requirements that are unique to the education sector [7]. The quality of the learning process was identified from the perceptions of college students and alumni on the implementation of the learning process in the PEP UNNES, as well as their expectations about it. The quality of graduates is measured by the absorption of graduates or alumni of PEP study programs (output and outcome) study programs in the world of work. The instrument used to dig up the information needed is developed by referring to the indicators or items listed in the Book III A accreditation form [8]. At the moment the tracer study is an absolute necessity because it is able to provide information about the quality of graduates or alumni of study programs, especially PEP study programs.

The problems faced by the college in conducting tracer studies are at the time of data collection. Some colleges still collect data manually by distributing questionnaire papers and telephone interviews with alumni and companies. Therefore, it is necessary to develop a tracer study based on website service that can provide information for universities in the interests of curriculum improvement, detailed alumni tracing and knowing the satisfaction of college graduates [9]. In this study, developing service of tracer study based on website.

\section{Methods}

The study is development research using the Waterfall model [12] with the aims of developing an online tracer study system based on the website in the PEP Study Program Graduate school UNNES. The sampling technique used purposive sampling.

\section{Result and Discussion}

\subsection{Expert Assessment of Developed Tracer Study Instruments}

The tracer study instrument that was developed before being used was tested for instrument validity first. Validity testing is done by involving experts. The expert provides an assessment of the instrument based on the material used, the design and flexibility of using the website. The results of the expert assessment of the tracer study instrument developed based on the display aspects were in the very appropriate category of $37.5 \%$ and the corresponding category of $62.5 \%$. Whereas in the aspect of instrument content, experts give values in the very appropriate category of $50 \%$ and in the appropriate category by $50 \%$. However, there are some inputs given by experts related to the instruments developed such as the usage instructions that must be displayed on the website with the aims of facilitating alumni and users to use the website, alumni response data that must be displayed with a graphical display to facilitate reading data or information. In addition, there is a need for alumni input facilities or forums as well as followup or feedback from PEP study program managers. 


\subsection{Online Tracer Study Based on Developed Websites}

The instrument of tracer study is an important matter in the process of gathering information on alumni and alumni users at universities. The tracer study instrument that was used as an instrument compiled by the PEP Study Program Graduate School UNNES in the process of gathering information. The instrument was prepared based on field needs with the aim of adjusting the operational conditions of the current PEP study program. The paper-based tracer study instrument was then distributed to alumni and alumni users through both expedition and face to face services, while soft file-based instruments were sent via E-mail, WhatsApp Messenger and Google Form. But what is considered most effective at that time was Google Form because it can collect data in a relatively fast time. But in its journey, Google Form still has limited access to information by users other than admin who have registered their e-mail when creating Google Form. In addition, there is an overlapping of data that enters an email so that the data must be separated based on the specified category. This certainly requires extra accuracy and the time has taken is long enough. Because of these limitations, a website-based online tracer study was developed which is expected to make it easier to collect and access data.

The results showed that by using an online tracer study based on the website, PEP Study Program Graduate School UNNES can collect data quickly and accurately. This is in line with the results of Rahmi's study, et al. Who got information through tracer study based on the website with a relatively fast and accurate time. In addition, general information of alumni and users can be accessed transparently so that it can facilitate alumni or college students who want to know alumni information [13]. In accordance with the opinion of Morley and Harvey (2001) in Castro \& Laguador (2016), there are six key generic skills used in user instruments namely communication, application of numbers, information technology, working with others, improving own learning and performance and problem-solving [17]

The results of Sudianto and Hidayati's research (2019) show that the existence of a tracer study based on the website can facilitate data collection and information about alumni and users [18] Likewise, with Setemen's research (2009), it shows that tracer based on the website is able to provide information about alumni that can be accessed by all parties in need, especially stakeholders, and especially for departments related to the graduation of graduates in the workforce. As in the Latif Research (2010) which states that in collecting data and information through tracer, there are two things that are related to alumni satisfaction data on study programs and alumni career development in the world of work [7]. The website also provides information related to the agenda to be carried out and activities that have been carried out by PEP.Visiting other private institutions, both academic and non-academic. The following is a display of online trace study based on the website was develop.

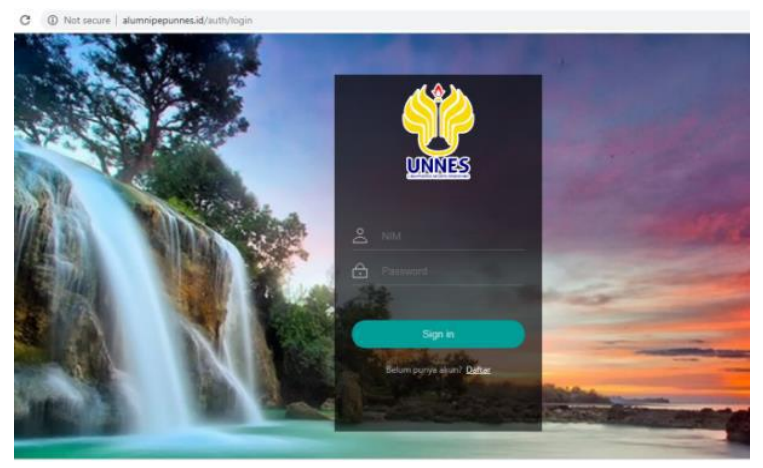

Figure 1. Admin and Alumni Login Page 


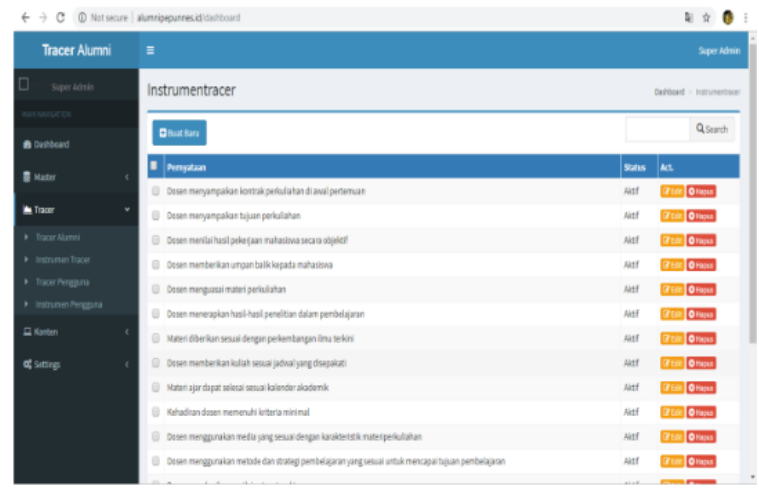

Figure.2. Instrument Page Tracer Alumni

\subsection{Perception of College College students and Alumni About the Quality of Learning in PEP UNNES}

PEP UNNES did not only carry out the learning process alone but also actively evaluates the quality of learning that has been running based on input from both students and alumni. These inputs were got based on the results of the tracer study instrument distributed to respondents. Evaluation results showed that most of the quality of the learning process was felt to have gone well done by lecturers such as the lecture contract delivery activities at the beginning of the meeting, delivery of lecture objectives, objective assessment of student work, delivery of feedback to students, mastery of material, application of results research in learning, giving material that is appropriate to the development of science and technology, completion of teaching materials that are appropriate to time, and so forth. For alumni, the quality of the learning process that has been carried out has gone quite well as long as the alumni undergo lectures at the PEP study program.

Therefore to improve its quality, there is still a need to improve efforts both in terms of curriculum and academic atmosphere. Many learning experiences got by alumni in the PEP study program, which include the academic atmosphere created by study programs both through cross-sectional meetings, emotional connections between students and students, between students and lecturers and between students have been well established. Things like this are considered to be continually developed as a culture in order to create a good academic atmosphere. However, it is undeniable that not all students were actively involved in some of the PEP study program activities due to time constraints, because some students besides lectures also worked while making it difficult to divide time.

Likewise with the opinion of Ghofur who stated that psychological problems faced that haunt students or learners must be eliminated. Therefore, the importance of the academic atmosphere must turn into a pleasant atmosphere, teaching behavior that is missed by students [14]. The same thing was also expressed by Kardoyo \& Nurkhin (2013) who stated that the study program must actively implement improvement and development activities, especially those related to students as customers [15]. Besides that, the study program must be able to capture the extent of satisfaction felt by students and alumni during and during the learning process. This is important to make "customers" as a means of promotion of study programs to prospective new students when choosing study programs at a certain college. 


\subsection{Expectations of College Students and Alumni towards Lectures in PEP UNNES}

Organizing an effective teaching and learning process is something that is highly expected by every educational institution. Every educational institution must be carried out a learning process that has an impact on the quality of graduates who are oriented to needs in the field. PEP study program has been striving to improve the quality of the learning process in various ways according to the expectations of Students College and alumni towards the progress of the study program. In addition to academic activities, the PEP is also active in conducting nonacademic activities in order to shape the character of students and alumni especially in strengthening friendship through cross-group meeting activities, student and alumni meetings, and so on. But for now, the expectations of students and alumni focus on developing academic quality that has an impact on the quality of graduates in terms of science.

Various inputs from students and alumni towards PEP such as providing complete and upto-date references in accordance with a scientific background, graduate competencies are expected to master and apply their knowledge in their fields of work, also in curriculum structure of study programs who needed by students. In addition, students and alumni expect the Study Program to be active in creating a conducive academic atmosphere both between students and between alumni by increasing extracurricular activities.

The input and expectations of the students and alumni were mostly carried out by the PEP such as data processing and analysis workshops, curriculum renewal, the provision of up-todate references in accordance with the scientific field, visits to institutions related to science. Some of the activities that have been carried out by the Study Program have been used as routine activities of the PEP in a sustainable manner such as processing and data analysis workshops involving other study programs in UNNES and outside UNNES. PEP continues to strive to improve their performance, both academic and non-academic performance so that the implementation of study programs still needs support from various parties, especially internal study programs such as lecturers, students, and alumni.

\section{Conclusion}

The results showed that the development of a study tracer based on the website can facilitate the data collection process for both alumni and users about responses related to the conduct of lectures at the PEP Study Program. Evidenced with study tracer based on a website, the data collected is relatively fast and the information got was classified as accurate. This can facilitate study programs in presenting data and information if at any time needed for the purposes of accreditation and other activities. The responses from alumni are very diverse, starting from the curriculum structure that needs to be addressed in accordance with field needs, a conducive academic atmosphere needs to be improved, activities that need to be conducted by study programs such as processing and data analysis workshops to support science in the research field. 


\section{References}

[1] Anonim.: Buku Panduan Prodi S2 PEP PPS UNNES. Tersedia online dihttp://pps.unnes.ac.id/prodi/program -studi-penelitian-dan-evaluasi-pendidikan diunduh 22 April 2018.pp. 27. (2015).

[2] Chaudhary, N. and Shankar, G.: A tracer study of Ignou Graduates. International Journal of Current Advanced Research. 5 (4), PP. 791- 798. (2016).

[3] Castro, E. and Laguador, J.: Tracer Study Of Engineering Graduates Of One Higher Education Institution In The Philippines For Academic YEAR 2009-2012. European Journal of Engineering and Technology , 4 (4), pp. 26-39. (2016).

[4] Macatangay, L.: Tracer Study OF BSCS Graduates OF Lyceum OF The Philippines Unversity From 2004-2009. Academic Research International, 4(5), pp. 361-377. (2013).

[5] Latif, L.: A.OUM's Tracer Study: A Testimony to a Quality Open and Distance Education. ASEAN Journal of Open and Distance Learning, 2(1), pp. 35-47.(2010)

[6] Setyorini, M.A. Nugroho, M.N. Aisyah, C. D. Sinangkling.: Tracer Study Kajian Relevansi Kemampuan Penguasaan Bahasa Asing Dan Teknologi Informasi Lulusan Program Studi Akuntansi FE UNY Tahun 2004-2011 dengan Kebutuhan User. Laporan Penelitian. Program Studi Akuntansi Jurusan Pendidikan Akuntansi Fakultas Ekonomi Universitas Negeri Yogyakarta. (2012)

[7] Siemens, G., Dawson, S. and Lynch, G.: Improving the Quality and Productivity of the Higher Education Sector, Society for Learning Analytics Research, pp. 1-35.(2013).

[8] Depdiknas, Badan Akreditasi Nasional PerguruanTinggi.: Akreditasi Program Studi pada Program Magister, Buku I-V, Naskah Akademik Sistem Akreditasi Program Magister Jakarta: Depdiknas, BAN-PT.(2002)

[9] Chandra, R., and Ruhama, S.: Pengembangan Sistem E-Tracer Study pada Perguruan Tinggi, KNSI, pp. 394-398. (2014).

[10] Putrama, I. M., Divayana, D. G. H., Suyasa, P. W. A.: Rancang Bangun Sistem Informasi Pengelolaan Data Kemahasiswaan untuk Akreditasi Program Studi di FTK Undiksha. Proceeding Semnasvoktek, 1,pp.9. (2016).

[11] Rahmi, A. N., Kusrini, Sudarmawan.: Pengembangan Sistem Tracer Study Online Berbasis Website di STMIK AMIKOM Yogyakarta. CSRID Journal, 6(2), pp. 108-117.(2014).

[12] Ghofur, A.: Pengaruh Suasana Akademik Terhadap Prestasi Belajar Bahasa Asing Mahasiswa Jurusan Bahasa Asing FBS Unimed. (2013).

[13] Kardoyo, Nurkhin, Ahmad.: Analisis Kepuasan Pelayanan Perguruan Tinggi (Kasus Pada Prodi Magister Pendidikan Ekonomi Unnes). Cakrawala Pendidikan. 1(2), pp. 164-175. (2014).

[14] City, B.: Tracer Study of Dentistry Graduates of one Higher Education Institution in the Philippines from 2008 to 2012, Asia Pacific Journal of Multidisiplinary Research, 4(3), pp. 160 167. (2016).

[15] Laguador, J and Dotong, C.: Tracer Study of BS Computer Engineering Graduates of Lyceum of the Philippines University. IJMIE 3(8), pp. 387-401. (2013). 